\title{
Tissue-specific expression and regulation of the haemolymph clottable protein of tiger shrimp (Penaeus monodon)
}

\author{
Maw-Sheng Yeh ${ }^{\text {a }}$, Chang-Jen Huang ${ }^{\text {b,c }}$, Jin-Hwa Cheng ${ }^{\text {d }}$, Inn-Ho Tsai ${ }^{\text {b,c,* }}$ \\ ${ }^{\text {a }}$ Department of Food and Nutrition, HungKuang University, Sha Lu, Taiwan \\ ${ }^{\mathrm{b}}$ Institute of Biological Chemistry, Academia Sinica, P.O. Box 23-106, Taipei, Taiwan \\ ${ }^{\mathrm{c}}$ Institute of Biochemical Sciences, National Taiwan University, Taipei, Taiwan \\ ${ }^{\mathrm{d}}$ Tungkang Branch Station, Fisheries Research Institute, Tungkang, Taiwan
}

Received 4 August 2006; revised 28 September 2006; accepted 25 October 2006

Available online 1 November 2006

\begin{abstract}
The clottable protein (CP) involved in Penaeus monodon haemolymph coagulation has previously been characterized and cloned. Polyclonal antibodies against purified CP were also prepared from rabbit serum. By Western blot analyses, we showed occurrence of CP in the shrimp central nervous system, gill, and lymphoid organ. Results of RT-PCR further indicated that the central nervous system, gill, and lymphoid organ transcribed more CP, heart and hepatopancreas transcribed less, while the haemocytes and the muscle did not. We further analyzed the $\mathrm{CP}$ distribution within shrimp lymphoid organ by immunohistochemical method, $\mathrm{CP}$ was found to localise in stromal cells of lymphoid organ rather than in the developing haemocytes. In addition, concentrations and regulation of the plasma $\mathrm{CP}$ under normal and artificially traumatic conditions were studied with rocket immunoelectrophoresis. The average plasma CP concentration in normal intermolt shrimps was elevated from $3 \mathrm{mg} \mathrm{ml}^{-1}$ to above $12 \mathrm{mg} \mathrm{ml}^{-1}$ after successive blood-withdrawing for a week. The production and secretion of CP apparently were increased more than 4 folds to compensate its loss. Our result also suggested that the shrimp sinus gland endocrine system is not directly required for the expression and up-regulation of CP.
\end{abstract}

(c) 2006 Elsevier Ltd. All rights reserved.

Keywords: Plasma coagulation and haemostasis; Western blot; RT-PCR; Immunohistochemistry; Shrimp (Penaeus monodon)

\section{Introduction}

Efficient immune systems and blood coagulation are of vital importance for the survival of both vertebrates and invertebrates. Haemolymph coagulation is part of the crustacean innate immune response; it prevents leakage of haemolymph from sites of injury and dissemination of invaders such as bacteria throughout the body. Two types of coagulation systems of invertebrates have been currently recognized [1]. One type consists of polymerisation of clotting

\footnotetext{
Abbreviations: CP, Clottable protein; PCR, polymerase chain reaction; SDS-PAGE, sodium dodecyl sulfate polyacrylamide gel electrophoresis.

* Corresponding author. Institute of Biological Chemistry, Academia Sinica, P.O. Box 23-106, Taipei, Taiwan. Tel.: +886 22 3620264; fax: +886223635038 .

E-mail address: bc201@gate.sinica.edu.tw (I.-H. Tsai).
} 
proteins $(\mathrm{CP})$ by haemocyte transglutaminases to form clot, e.g. the clotting systems of crustaceans [2-9] and insects $[1,10]$. The other type consists of proteolytic cascades which are activated by foreign agents (e.g. the microbial cell wall), and coagulogen molecules are subsequently cleaved and insolubilised, such as the coagulation system of horseshoe crabs [11].

The plasma CPs from various crustacean species have been characterized [4-9,12,13]. Lobster CP is a homodimeric glycoprotein of about $400 \mathrm{kDa}$ which forms stable clots in the wound area [12]. Its crystal structure was elucidated by single particle reconstitution and a possible site for lipid-binding was identified [14]. Two shrimp CP genes were cloned and their deduced amino acid sequences showed similarities to those of vitellogenins $[15,16]$. In addition to a clotting role, the CPs were found to be involved in lipid transport $[5,8,9,17]$. On the other hand, the haemocyte clotting enzymes or transglutaminases of tiger shrimp (Penaeus monodon) [18-20] and of crayfish Pacifastacus leniusculus [21] have been cloned and characterized. Upon releasing from haemocytes, the transglutaminases are activated by physiological level of plasma calcium ion to start the coagulation.

Regulation of plasma coagulation in invertebrates is not as well-studied as those in vertebrates. Invertebrate models may also shed light on the general principles of haemostasis. The model we studied herein is $P$. monodon, which is an economically important prawn cultured in Taiwan and southeastern Asia. Contents of shrimp haemolymph are closely related with the coagulation, haemostasis and physiological conditions of the animals [22]. To elucidate the expression and regulation of the shrimp plasma CP, we examined the CP expression levels by RT-PCR and immunochemical methods. Regulation of CP concentration in normal and artificially traumatic conditions was studied by rocket immunoelectrophoresis. Possible hormonal control of CP expression by the shrimp sinus glands was also investigated.

\section{Material and methods}

\subsection{Haemolymph collection}

Shrimps (20-25 g each) were purchased from local markets and kept in aerated seawater. Haemolymph (0.6$1.0 \mathrm{ml}$ ) was withdrawn from the ventral sinus located in the first abdominal segment, using a $23 \mathrm{G}$ gauged $2.5 \mathrm{ml}$ syringe containing $0.06-0.1 \mathrm{ml}$ anticoagulant $(50 \mathrm{mM}$ EGTA, $18 \mathrm{mM}$ Tris- $\mathrm{HCl}, 0.35 \mathrm{M} \mathrm{NaCl}, 13 \mathrm{mM} \mathrm{KCl}$, $1.67 \mathrm{mM}$ D-glucose, $\mathrm{pH}$ 7.5) [23]. Haemocytes were immediately spun down at $300 \times g, 4{ }^{\circ} \mathrm{C}$ for $10 \mathrm{~min}$, and the supernatant was pooled for preparing the plasma CP.

\subsection{Protein purification and analyses}

The plasma was dialyzed against TE buffer (50 mM Tris- $\mathrm{HCl}, 1 \mathrm{mM}$ EDTA, $\mathrm{pH} 8.0)$ at $4{ }^{\circ} \mathrm{C}$ for $14 \mathrm{~h}$. It was twice subjected to ion exchange chromatography at $4{ }^{\circ} \mathrm{C}$ with a TSK DEAE-650 (S) column $(2.5 \mathrm{~cm} \times 9 \mathrm{~cm})$ equilibrated with TE buffer, once with and once without $0.1 \mathrm{M} \mathrm{NaCl}$. The CP was eluted with a step-wise gradient of $\mathrm{NaCl}(0.21$, 0.24 and 0.3 M, sequentially) [6]. Protein concentrations were determined by the Bradford method [24], using bovine serum albumin as standard.

The purified CP was subjected to SDS-PAGE [25] with a 5\% gel, and stained with Coomassie brilliant blue R-250. Molecular mass markers: myosin $(212 \mathrm{kDa}), \beta$-galactosidase $(116 \mathrm{kDa})$, phosphorylase $\mathrm{B}(97 \mathrm{kDa})$, bovine serum albumin $(66 \mathrm{kDa})$, catalase $(57 \mathrm{kDa})$, and aldolase $(40 \mathrm{kDa})$ were obtained from Promega Co. (USA).

\subsection{Antiserum}

After the SDS-PAGE, the $190 \mathrm{kDa}$ CP protein-band was stained, cut and eluted from the gel. It was lyophilised and portions were dissolved in adjuvant to immunise New Zealand White rabbits by subcutaneous injections. Polyclonal antibodies against $\mathrm{CP}$ were induced and harvested from the rabbit serum [26].

\subsection{Isolation of RNA from various tissues and RT-PCR}

Total RNA was isolated from central nervous system, gill, heart, haemocyte, hepatopancreas, lymphoid organ, and muscle of $P$. monodon using the RNAzol reagent (Biotecx, Friendswood, TX, USA). First-strand cDNA was amplified from $2 \mu \mathrm{g}$ total RNA using 10 pmol oligo-dT primer in a $25 \mu \mathrm{L}$ reaction containing $30 \mathrm{U}$ RNasin (Promega), $1 \mathrm{~mm}$ 
dNTP, $10 \mathrm{~mm}$ dithiothreitol, and 300 U Superscript II (Life Technologies). Synthesized cDNA was used as templates in subsequent polymerase chain reaction (PCR) [27]. Abundance of CP mRNA in the tissue was examined by RTPCR with one pair of primers (forward, 5'-GAGGGCATGTGAGAACCATCAGTGTGG-3' and reverse, 5'GTAATGTTCTTCAGGTTGTCTGGGAAG-3'). The actin mRNA which served as internal control was amplified with another pair of primers (forward, 5'-CCGTCATCAGGGTGTGATGGT-3' and reverse, 5'-CCACGCTCAGT CATGATCTTCA-3') based on conserved regions of tiger shrimp actin genes (accession nos. AF100987 and AF100986). The PCR program was the following: denaturation at $94{ }^{\circ} \mathrm{C}$ for $2 \mathrm{~min}$, followed by $25-35$ cycles of $30 \mathrm{~s}$ at $94{ }^{\circ} \mathrm{C}, 30 \mathrm{~s}$ at $53{ }^{\circ} \mathrm{C}, 30 \mathrm{~s}$ at $72{ }^{\circ} \mathrm{C}$, and a final polymerisation step at $72{ }^{\circ} \mathrm{C}$ for $5 \mathrm{~min}$. PCR products were analyzed by electrophoresis on $1.2 \%$ agarose gel containing ethidium bromide. As expected, the PCR product of CP cDNA was about 497 bp while amplified actin gene was 474 bp.

\subsection{Preparation of tissue homogenate}

Preparation of the homogenates followed the methods of Dignam [28]. Briefly, tissues from the shrimp were cut into pieces and put in iced-cold Buffer A (50 mM Tris, pH 7.5; 2 mM EDTA, $150 \mathrm{mM} \mathrm{NaCl}, 0.5 \mathrm{mM}$ dithiothreitol) and washed with large volume of iced-cold Buffer A three times on ice. Cautions were taken to avoid contamination of these tissues by plasma CP. Then, they were homogenised in iced-cold Buffer B (50 mM Tris, pH 7.5; $10 \%$ glycerol, $5 \mathrm{mM}$ magnesium acetate, $0.2 \mathrm{mM}$ EDTA, $0.5 \mathrm{mM}$ dithiothreitol, $1 \mathrm{mM}$ serine protease inhibitor phenylmethylsufonyl fluride) with polytron on ice. Each tissue was immediately centrifuged at $12,000 \times g$ for 30 min at $4{ }^{\circ} \mathrm{C}$ and only the supernatant was collected. Protein concentrations of the tissue extracts were determined by the Bradford method [24], $20 \mu \mathrm{g}$ proteins for each tissue were analyzed by Western blot.

\subsection{Immunoblot and immunohistochemistry}

Purified CP in the presence of reducing agent was analyzed by SDS-PAGE (5\% gel) and transferred electrophoretically to a PVDF membrane [29]. The blotted membrane was allowed to react with rabbit anti-CP antibodies followed by incubation with alkaline phosphatase-conjugated goat anti-rabbit IgG. A colour reaction was generated by adding nitroblue tetrazolium and 5-bromo-4-chloro-3-indolyl phosphate. For immunohistochemical studies [26], shrimp tissues including lymphoid organ and maxilliped area were fixed in the Davidson's solution and their paraffin sections were prepared [30]. Deparaffinised sections were treated with $1 \% \mathrm{H}_{2} \mathrm{O}_{2}$ in methanol for 25 min to minimise endogenous peroxidase activity. They were then incubated with the anti-clottable protein antibodies and horseradish peroxidase-conjugated goat anti-rabbit IgG antibodies. The antigen was located by staining with a mixture of peroxidase enzyme substrate and 3,3'-diaminobenzidine tetrahydrochloride.

Additionally, nuclei were stained with haematoxylin, dehydrated in ethanol, cleared in xylene, and mounted in DPX (BDH, Co.). The slides were also stained with haematoxylin-eosin for histological characterization. The shrimp haemolymph was freshly withdrawn and fixed with $10 \%$ formaline in $2.25 \mathrm{X}$ PBS for $15 \mathrm{~min}$ at room temperature. Haemocytes were spun down at $1000 \times g$ for $10 \mathrm{~min}$ and washed with PBS, then smeared on slides. The slides were permealised with methanol and overlaid with anti-CP antibodies and fluorescein isothiocyanate-conjugated goat anti-rabbit IgG for $30 \mathrm{~min}$. Finally, they were mounted in buffered glycerin for observation under a fluorescence microscope (Olympus AHBS3, Japan).

\subsection{Culture and management of shrimp}

Healthy $P$. monodon were cultured in a plastic tank supplied with constantly flowing seawater. They were fed synthetic feed pellets, equivalent to 5\% of their body weight, twice a day, for more than 1 month before the study. Five shrimps (20-25 g each) were used in each group, and about $0.1 \mathrm{ml}$ haemolymph was withdrawn from each shrimp daily for a week. After haemolymph withdrawing, the shrimps were returned to the seawater tank immediately.

\subsection{Rocket immunoelectrophoresis of $C P$}

Plasma CP concentrations of normal intermolt shrimps, uropod-ablated shrimps and both-eyestalks-ablated shrimps were analyzed by rocket immunoelectrophoresis [31]. The concentrations were calculated from the height of 
precipitation peak in the gel after electrophoresis and dye-staining ( $0.5 \%$ Coomasie blue), using a calibration curve of rocket height constructed from the purified CP [23]. Concentrations of total plasma protein were also determined [24].

\section{Results and discussion}

\subsection{Gel analyses of $C P$}

We have purified CP from the haemolymph of P. monodon and its purity and molecular weight [6] was confirmed by 5\% SDS-PGE (Fig. 1A). The protein was also subjected to Western blot analysis, a native form of $190 \mathrm{kDa}$ and a minor truncated form of $180 \mathrm{kDa}$ were detected on the PVDF membrane (Fig. 1B).

\subsection{Western blot analyses of tissue distribution of $C P$}

Shrimps have an open circulation system, we used merely $20 \mu \mathrm{g}$ proteins from each tissue extract and tried to minimise haemolymph CP contamination in the experiments. As shown in Fig. 2, the CP was abundantly expressed in CNS and gill, less expressed in lymphoid organ, and hardly detected in heart, hepatopancreas, muscle and haemocytes. Since a minor portion of CP appeared to be degraded by endogenous proteases during its purification from the haemolymph (Fig. 1B, Ref. [6]), we were not surprised to detect a degraded CP in the gill extract (Fig. 2, lane 4). Some tissues preparations stained weakly in Fig. 2, they either did express little CP or they were contaminated with the plasma.

\section{3. $R T-P C R$}

The transcription of CP in various shrimp tissues was also analyzed by RT-PCR. The CP mRNA was expressed in the decreasing order as follows: gill, central nervous system, lymphoid organ, heart, hepatopancreas, haemocytes and muscle (Fig. 3). Notably, it was not expressed in the haemocytes, in accord with the finding by previous Northern blot analyses [14]. Taken together the experimental results, we may conclude that gill, central nervous system, and lymphoid organ are the major sites for CP transcription and production in tiger shrimp. It is known that fibrinogen of vertebrate was produced and secreted in liver. Interestingly, this is the first time that the nervous system has been shown to transcribe and translate the CP (Figs. 2 and 3), its physiological significance remains to be investigated.

\subsection{Immunostaining of $C P$ in lymphoid organ}

Lymphoid organ, located ventro-lateral to the junction of the anterior and posterior stomach chamber [32], is part of the haematopoietic tissues in penaeid shrimps [33]. Another shrimp haematopoietic tissue is at the epigastric area and

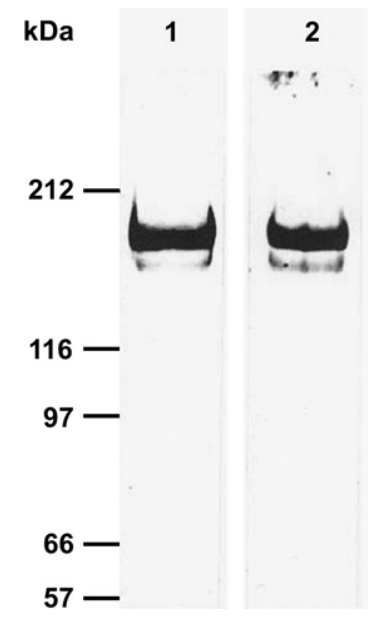

Fig. 1. Homogeneity of the purified CP of P. monodon. (1) SDS-PAGE (on a 5\% gel); (2) Western blot. 


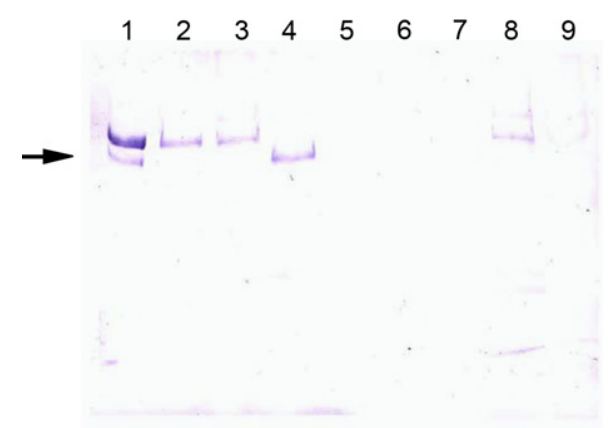

Fig. 2. Western blot analyses of $\mathrm{CP}$ in various $P$. monodon tissues. Extracts containing $20 \mu \mathrm{g}$ proteins were loaded onto the gel; Lane 1, purified $\mathrm{CP}$ (positive control); lane 2, haemolymph; lane 3, central nervous system; lane 4, gill; lane 5, heart; lane 6, haemocytes; lane 7, hepatopancreas; lane 8, lymphoid organ; and lane 9, muscle. Arrow indicates a degradation form of $\mathrm{CP}$.

within the first three maxillipeds [30,33]. Upon maturation, shrimp haemocytes were released from the haematopoietic tissues into haemolymph. Western blot to detect CP protein and RT-PCR to detect its mRNA showed negative results for the haemocytes, but positive results for lymphoid organ (Figs. 2 and 3). Whether CP is expressed in haemocytes during its early stages of cell development was further checked using a highly specific anti-CP antibody [6] (Fig. 1B). The results based on a sensitive immunostaining of the paraffin sections of shrimp haematopoietic tissues showed a low expression level of CP in the lymphoid organ and maxillipeds (Figs. 2 and 3). Moreover, the CP was localised in the outer layer of stromal matrix cells of lymphoid organ, but not in the haematopoietic cells (Fig. 4B), nor the area of first three maxillipeds and circulating haemocytes (data not shown). Thus, the CP gene appears to be silent in the haemocyte during generation and development.

\subsection{Regulation of plasma CP after bleeding}

In order to better understand the regulation of $\mathrm{CP}$ in tiger shrimp, we monitored the haemolymph $\mathrm{CP}$ concentrations by rocket immunoelectrophoresis. The total plasma protein concentrations were also monitored by the Bradford method during entire experimental period. The plasma protein concentrations in control group were $125.6 \pm 12.7 \mathrm{mg} \mathrm{ml}^{-1}$ plasma and gradually decrease to $89.3 \pm 18.3 \mathrm{mg} \mathrm{ml}^{-1}$ after repetitive blood-withdrawn for a week (Fig. 5A). In eyestalk- and uropod-ablated shrimps, the total plasma protein was also decreased by 25-30\% as compared with the normal control (Fig. 5A). Previous rocket immunoelectrophoresis analyses of the $\mathrm{CP}$ showed that the rocket height was proportional to the quantity of the purified antigen (used for calibration) in the range of 1-20 $\mu \mathrm{g}$ [23]. In traumatic condition, the total plasma protein synthesis was decreased by about $40 \%$. The CP concentration in normal intermolt shrimps was $3.0 \pm 1.5 \mathrm{mg} \mathrm{ml}^{-1}$ in haemolymph (Fig. 5B) and it was elevated to $12.1 \pm 0.5 \mathrm{mg} \mathrm{ml}^{-1}$ upon successive bleeding for a week. Apparently, biosynthesis of the CP was increased to compensate for its loss. This is consistent with a wound-healing role of the protein.

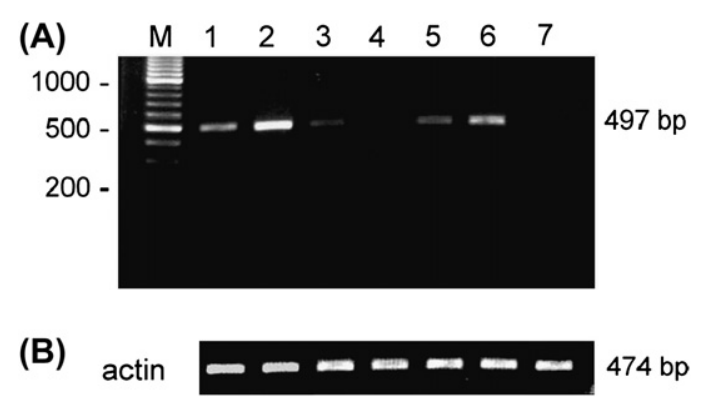

Fig. 3. Transcription of CP in various shrimp tissues. PCR products at 25 cycles were analyzed by electrophoresis on $1.2 \%$ agarose gel containing ethidium bromide. (A) RT-PCR analysis of CP mRNA levels in shrimp tissues by amplifing a 497-bp fragment of the mRNA. Lane 1, central nervous system; lane 2, gill; lane 3, heart; lane 4, haemocytes; lane 5, hepatopancreas; lane 6, lymphoid organ; and lane 7, muscle. (B) As an internal control, actin mRNAs in the tissues were amplified. 
(A)

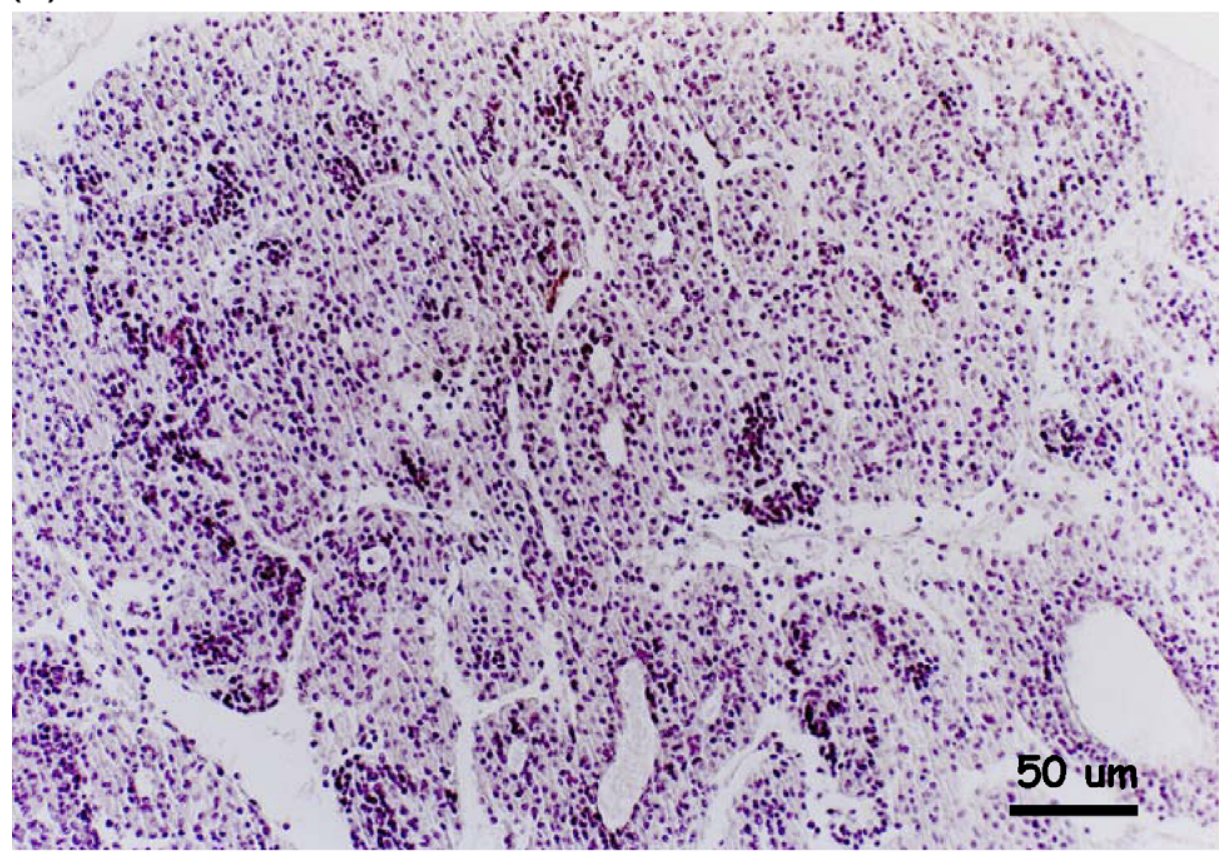

(B)

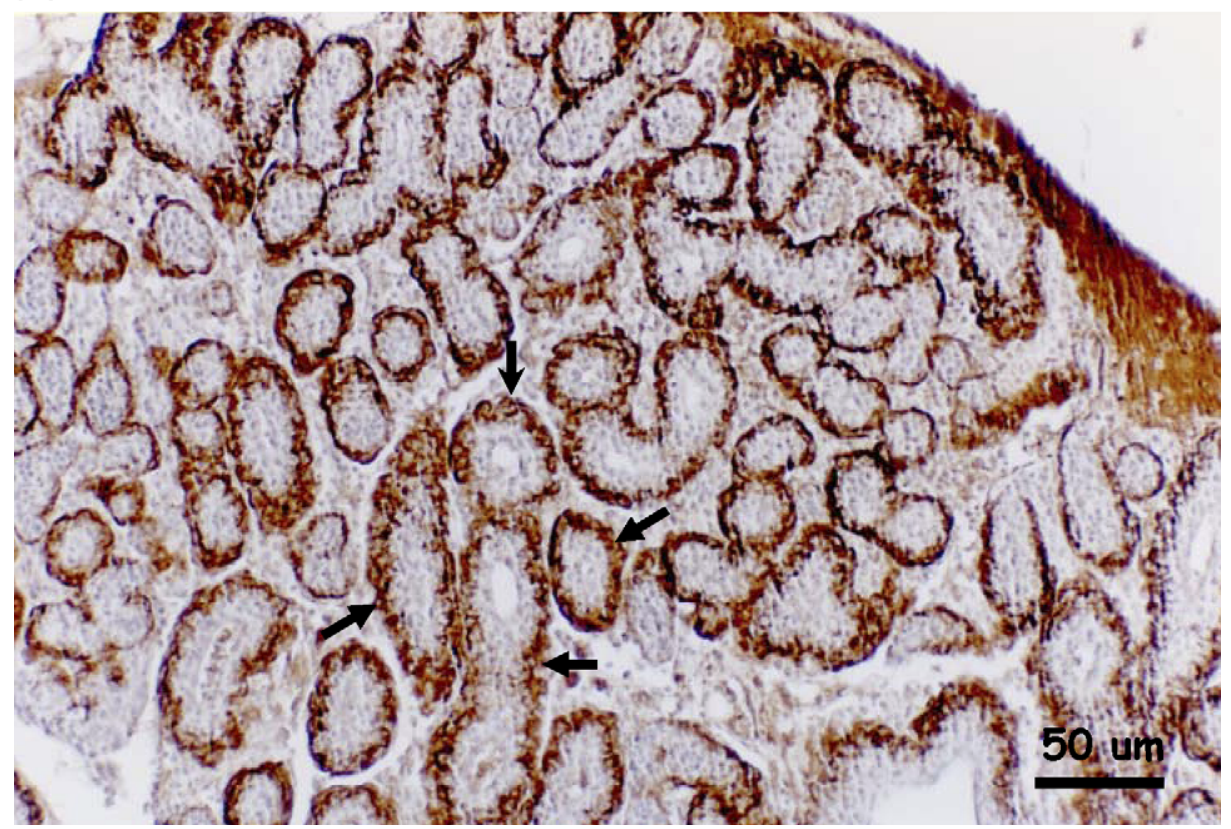

Fig. 4. Identification of CP expression cells in shrimp lymphoid organ. Fixed lymphoid organ sections were subjected to haematoxylin-eosin staining (A) and immunostaining (B). Arrows point to the positively stained area of stromal matrix cells of lymphoid organ. Bar indicates $50 \mu \mathrm{m}$ in length.

\subsection{Possible involvement of sinus glands}

Eyestalks of shrimps contain sinus glands, which secret hormones to regulate pigment distribution, haemolymph glucose level, molting, and gonad-development of the shrimp [34-37]. Whether the sinus glands also regulate $\mathrm{CP}$ expression was tested by eyestalk ablation. Similar to the results of uropod-ablated shrimps, the 

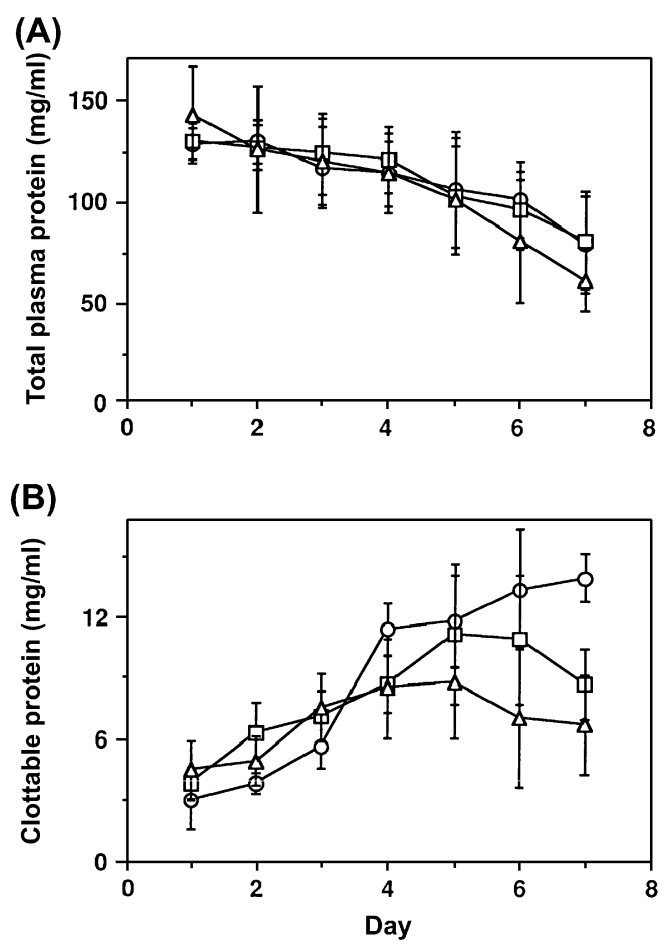

Fig. 5. Induction of CP expression under special experimental conditions. Daily change of the concentrations of (A) total plasma proteins; (B) plasma CP was monitored after daily withdrawal of $0.1 \mathrm{ml}$ haemolymph. Five specimens were used in each group: $\bigcirc$, normal group, $\square$, uropodablated group, $\triangle$, eyestalk-ablated group. Data were expressed as means $\pm \mathrm{SE}$.

$\mathrm{CP}$, concentrations of eyestalk-ablated shrimps reached 3 folds of its basal level on the 4th day, and peaked on the 5th day $\left(11.5 \pm 1.7 \mathrm{mg} \mathrm{m}^{-1}\right.$ ) (Fig. 5B). Apparently, shrimps without the sinus glands maintained a CP replenish mechanism (Fig. 5B), thus sinus glands probably are not required for the up-regulation of CP synthesis.

\section{Conclusion}

The present study showed that gill, central nerve system and lymphoid organ are the major tissues producing CP in tiger shrimp, and CP gene is not expressed in mature or developing shrimp haemocytes. It seems reasonable for the shrimp homeostasis that the clotting substrate $(\mathrm{CP})$ is well separated from the clotting enzyme (transglutaminase in haemocytes) before coagulation takes place. Our data also confirmed that plasma levels of shrimp CP was sensitively controlled to maintain haemostasis and could be replenished in traumatic conditions. However, the sinus gland endocrine system appears not necessary for the expression and up-regulation of CP.

\section{Acknowledgments}

We thank Prof. Shiu-Nan Chen and Miss Shuan Tzeng for assistance in the immunohistochemical analysis, and Dr. Yuh-Ling Chen for assistance in rocket immunoelectrophoresis. This research was supported by grants from Academia Sinica, Taiwan, and HungKuang University, Taiwan, ROC.

\section{References}

[1] Theopold U, Schmidt O, Soderhall K, Dushay MS. Coagulation in arthropods: defense, wound closure and healing. Trends Immunol 2004;25:289-94.

[2] Durliat M. Clotting process in crustacean decapoda. Biol Rev 1985;60:473-98.

[3] Martin GG, Hose JE, Omori S, Chong C, Hoodbhoy T, MacKrell N. Localization and roles of coagulogen and transglutaminase in hemolymph coagulation in decapod crustaceans. Comp Biochem Physiol 1991;100B:517-22. 
[4] Kopacek P, Hall M, Soderhall K. Characterization of a clotting protein, isolated from plasma of the freshwater crayfish Pacifastacus leniusculus. Eur J Biochem 1993;213:591-7.

[5] Komatsu M, Ando S. A very-high-density lipoprotein with clotting ability from hemolymph of sand crayfish, Ibacus ciliatus. Biosci Biotechnol Biochem 1998;62:459-63.

[6] Yeh MS, Chen YL, Tsai IH. The hemolymph clottable proteins of tiger shrimp, Penaeus monodon, and related species. Comp Biochem Physiol 1998;121B:169-76.

[7] Montano-Perez K, Yepiz-Plascencia G, Higuera-Ciapara I, Vargas-Albores F. Purification and characterization of the clotting protein from the white shrimp Penaeus vannamei. Comp Biochem Physiol 1999;122B:381-7.

[8] Yepiz-Plascencia G, Jiménez-Veja F, Romo-Figueroa MG, Sotelo-Mundo RR, Vargas-Albores F. Molecular characterization of the bifunctional VHDL-CP from the hemolymph of the white shrimp Penaeus vannamei. Comp Biochem Physiol 2002;132B:585-92.

[9] Perazzolo LM, Lorenzini DM, Daffre S, Barracco MA. Purification and partial characterization of the plasma clotting protein from the pink shrimp Farfantepenaeus paulensis. Comp Biochem Physiol 2005;142B:302-7.

[10] Bohn H, Barwig B. Hemolymph clotting in the cockroach Leucophaea maderae (Blattaria). Influence of ions and inhibitors; isolation of the plasma coagulogen. J Comp Physiol 1984;154B:457-67.

[11] Kawabata SL, Muta T, Iwanaga S. The clotting cascade and defense molecules found in the hemolymph of the horseshoe crab. In: Soderhall K, Iwanaga S, Vasta GR, editors. New directions in invertebrate immunology. Fair Haven: SOS Publications; 1996. p. $255-83$.

[12] Durliat M, Vranckx R. Action of various anticoagulants on hemolymph of lobster and spiny lobsters. Biol Bull 1981;160:55-68.

[13] Doolittle RF, Riley M. The amino-terminal sequence of lobster fibrinogen reveals common ancestry with vitellogenins. Biochem Biophys Res Commun 1990;167:16-9.

[14] Kollman JM, Quispe RF. The $17 \AA$ structure of the $420 \mathrm{kDa}$ lobster clottable protein by single particle reconstruction from cryoelectron micrographs. J Struct Biol 2005;151:306-14.

[15] Yeh MS, Huang CJ, Leu JH, Lee YC, Tsai IH. Molecular cloning and characterization of a hemolymph clottable protein from tiger shrimp (Penaeus monodon). Eur J Biochem 1999;266:624-33.

[16] Hall M, Wang R, van Antwerpen R, Sottrup-Jensen L, Soderhall K. The crayfish plasma clotting protein: a vitellogenin-related protein responsible for clot formation in crustacean blood. Proc Natl Acad Sci USA 1999;96:1965-70.

[17] Hall M, van Heusden MC, Soderhall K. Identification of the major lipoproteins in crayfish hemolymph as proteins involved in immune recognition and clotting. Biochem Biophys Res Commun 1995;216:939-46.

[18] Huang CC, Sritunyalucksana K, Soderhall K, Song YL. Molecular cloning and characterization of tiger shrimp (Penaeus monodon) transglutaminase. Dev Comp Immunol 2004;28:279-94.

[19] Chen MY, Hu KY, Huang CC, Song YL. More than one type of transglutaminase in invertebrates? A second type of transglutaminase is involved in shrimp coagulation. Develop Comp Immunol 2005;29:1003-16.

[20] Yeh MS, Kao LR, Huang CJ, Tsai IH. Biochemical characterization and cloning of transglutaminases responsible for hemolymph clotting in Penaeus monodon and Marsupenaeus japonicus. Biochim Biophys Acta 2006;1764:1167-78.

[21] Wang R, Liang Z, Hall M, Soderhall K. A transglutaminase involved in the coagulation system of the freshwater crayfish, Pacifastacus leniusculus. Tissue localization and cDNA cloning. Fish Shellfish Immunol 2001;11:623-37.

[22] Song YL, Yu CI, Lien TW, Huang CC, Lin MN. Haemolymph parameters of Pacific white shrimp (Litopenaeus vannamei) infected with Taura syndrome virus. Fish Shellfish Immunol 2003;14:317-31.

[23] Chen YL, Huang SH, Cheng JH, Tsai IH. Relationship between hemolymph coagulation and disease in shrimps: (II) Purification and characterization of the hemolymph coagulogen of Penaeids (COA Fisheries Series, No. 40, Taiwan, R.O.C.). Fish Dis Res 1993;13:1-9.

[24] Bradford MM. A rapid and sensitive method for the quantitation of microgram quantities of proteins utilizing the principle of protein-dye binding. Anal Biochem 1976;72:248-54.

[25] Neville Jr DM. Molecular weight determination of protein dodecyl sulfate complexes by gel electrophoresis in a discontinuous buffer system. J Biol Chem 1971;246:6328-34.

[26] Harlow E, Lane D. Antibodies, a laboratory manual. NY: Cold Spring Harbor Laboratory; 1988.

[27] Mullis KB, Faloona FA. Specific synthesis of DNA in vitro via a polymerase-catalyzed chain reaction. Methods Enzymol 1987;155:335-50.

[28] Dignam JD. Preparation of extracts from higher eukaryotes. Methods Enzymol 1990;182:194-203.

[29] Towbin H, Staehelin T, Gordon J. Electrophoretic transfer of proteins from polyacrylamide gels to nitrocellulose sheets: procedure and some application. Proc Natl Acad Sci USA 1979;76:4350-4.

[30] Thomas AB, Lightner DV. A handbook of normal penaied shrimp histology. USA: Allen Press; 1988.

[31] Laurell CB. Quantitative estimation of proteins by electrophoresis in agarose gel containing antibodies. Anal Biochem 1966;15:45-52.

[32] Oka M. Studies on Penaeus orientalis Kishinouye. VIII. Structure of newly found lymphoid organ. Bull Japan Soc Sci Fish 1969;35:245-50.

[33] Martin GG, Hose JE. Vascular element and blood (hemolymph). In: Harrison FW, Humes AG, editors. Microscopic anatomy of invertebrates, vol. 10. New York: Wiley-Liss Press; 1992. p. 117-46.

[34] Fingerman M. Glands and secretion. In: Harrison FW, Humes AG, editors. Microscopic anatomy of invertebrates, vol. 10. New York: WileyLiss Press; 1992. p. 345-56.

[35] Devaraj H, Natarajan A. Molecular mechanisms regulating molting in a crustacean. FEBS J 2006;273:839-46.

[36] Ollivaux C, Vinhj J, Soyez D, Toullec JY. Crustacean hyperglycemic and vitellogenesis-inhibiting hormones in the lobster Homarus gammarus. FEBS J 2006;273:2151-60.

[37] Fanjul-Moles ML. Biochemical and functional aspects of crustacean hyperglycemic hormone in decapod crustaceans: review and update. Comp Biochem Physiol 2006;142C:390-400. 